\title{
Актуализация нравственного и правового сознания и поведения граждан и противодействия криминальной субкультуре и экстремизму в современном обществе
}

\author{
(C) Дамаскин Олег Валерьевич, \\ доктор юридических наук, профессор, заслужен- \\ ный юрист Российской Федерации, главный \\ научный сотрудник Института государства и \\ права РАН \\ (C) Ясницкая Мария Иосифовна, \\ младший научный сотрудник Института госу- \\ дарства и права РАН
}

\begin{abstract}
Аннотация. На основе обзора и анализа трансформации современного общества, государства и права, кризиса нравственной и правовой культуры, состояния преступности, экстремизма и коррупции, рассматриваются потребности и возможности научного криминолого-правового обеспечения противодействия криминальной субкультуре и экстремизму в методологии и социально-правовой практике.
\end{abstract}

Ключевые слова: правовая культура, правовое сознание, преступность, экстремизм, коррупция.

\section{Updating the moral and legal consciousness and behavior of citizens and countering criminal subculture and extremism in modern society}

\author{
(C) Damaskin O. V., \\ doctor of law, Professor, honored lawyer of the Rus- \\ sian Federation, chief researcher of the Institute of \\ state and law of the Russian Academy of Sciences \\ (C) Yasnitskaya M. I., \\ Junior researcher At the Institute of state and law of \\ the Russian Academy of Sciences.
}

Annotation. Based on the review and analysis of the transformation of modern society, state and law, the crisis of moral and legal culture, the state of crime, extremism and corruption, the needs and opportunities of scientific criminal and legal support for countering criminal subculture and extremism in methodology and socio-legal practice are considered.

Keywords: legal culture, legal consciousness, crime, extremism, corruption.

1. Правовая культура: правовое сознание и поведение.

Президент Российской Федерации В. В. Путин считает, что человечество столкнулось с утратой нравственных ценностей и нуждается в переосмыслении своей миссии на Земле. Такое мнение он высказал в ходе выступления на ежегодном заседании дискуссионного клуба «Валдай» 22 октября 2020 г. «Вот что ин- тересно: человечество достигло высокого технологического и социальноэкономического уровня. И вместе с тем столкнулось с утратой, размыванием нравственных ценностей, потерей ориентиров и ощущения смысла существования. Если хотите - миссией человека на Земле», - сказал он. Такой кризис, по 
мнению главы государства, не разрешается путем дипломатических переговоров или созыва крупной международной конференции. «Он требует переоценки приоритетов и переосмысления целей. И начинать нужно с себя: с каждого человека, сообщества, государства. А уже потом бороться за мировое устройство» ${ }^{1}$ - подчеркнул В. В. Путин.

Современная трансформация общества, государства и права ${ }^{2}$ актуализирует проблему преступности в XXI в. ${ }^{3}$ : противодействия криминальной субкультуре и экстремистским проявлениям ${ }^{4}$. Исследования констатируют существенное влияние изменений социально-экономических условий бытия на состояние юридической психологии и деформацию индивидуального и группового правосознания людей ${ }^{5}$. Эти процессы проявляются наиболее остро в подростковой и молодежной среде, что выражается в нарастающем экстремизме и противоправном поведении ${ }^{6}$.

Усиливаются тенденции индивидуализма, агрессии. Традиционные меры поддержания правопорядка утрачивают свою действенность в новых условиях сетевых информационных технологий, использования транснациональной преступности в гибридных формах организуемого хаоса, посягательства на традиционный правопорядок ${ }^{7}$.

\footnotetext{
${ }^{1}$ Российская газета. 2020. 22 октября.

2 Савенков А. Н. Государство и право в период кризиса современной цивилизации : монография. М.: Проспект, 2020.

3 Преступность XXI века. Транснациональный характер. Теневая экономика. Влияние на государство : сб. науч. тр. М.: ЮНИТИ-ДАНА: Закон и право, 2019.

4 Противодействие современной преступности. Криминологические, уголовно-правовые и уголовно-процессуальные аспекты : монография / под общ. ред. чл.-корр. РАН А. Н. Савенкова. М.: ЮНИТИ-ДАНА: Закон и право, 2019.
}

5 Трансформация парадигмы права в цивилизационном развитии человечества : доклады членов РАН / под общ. ред. чл.-корр. РАН А. Н. Савенкова. М.: ИГП РАН, 2019.

6 Дамаскин О. В. Криминологические аспекты детерминации современного экстремизма и терроризма : монография. М.: Юрлитинформ, 2018.

7 Дамаскин О. В. Транснациональная организованная преступность: проблемы международной и
Между правом как системой норм, с одной стороны, и реальным поведением, предписанным или запрещенным этими нормами, с другой стороны, находится посредствующее звено - человеческое сознание.

Отражая социальную действительность, сознание познает и усваивает существующие нормы, определенным образом оценивает их, признавая или отвергая, и в той или иной мере руководствуется ими, направляя реальное поведение. Таким образом, сознание, являясь непосредственным источником активности и регулятором человеческого поведения, само испытывает регулирующее воздействие внешних явлений, к числу которых относится действующее право, практика его применения и иные явления правовой действительности. Сферу индивидуального, группового и общественного сознания, которая отражает правовые явления, принято именовать правосознанием.

Потребности эмпирического исследования правового сознания обусловливают необходимость уяснения и уточнения понятийного аппарата этой проблемы. Для построения теоретической модели и вытекающих из нее рабочих гипотез имеющаяся в нашей философской, социологической и юридической литературе общетеоретическая трактовка правосознания играла методологическую, направляющую роль. Вместе с тем, конкретное исследование требовало операциональных определений правосознания не только как явления в целом, но и его структуры, составляющих элементов, функций и механизма взаимодействия с другими сферами духовной жизни общества. Чтобы понять механизм превращения правосознания из явления идеального и непосредственно не наблюдаемого в нечто объективированное и доступное изучению, необходимо рассматривать его в более широком контексте, используя понятие, способное охватить и правосознание, и осязаемые формы его проявления. Таким понятием служит правовая культура. В состав правовой культу-

национальной безопасности : монография. М.: Юрлитинформ, 2019. 
ры входят следующие наиболее крупные культурные комплексы:

- право, как система норм, выражающих государственные веления;

- правоотношения, как система общественных отношений, регулируемых правом;

- правовые учреждения (институты) как система государственных органов и общественных организаций, обеспечивающих правовой контроль, регулирование и исполнение права;

- правовое поведение, как система практической деятельности людей по исполнению и применению права;

- правосознание, как система духовного отражения всей правовой действительности.

Правовое опосредствование касается всех сторон общественной жизни. Правовым регулированием в большей или меньшей степени охватываются и производственно-трудовые, и политические, и лично-имущественные, и семейнородственные, и бытовые, и многие иные отношения.

Не имея дискретного характера, правовая культура состоит в сложном органическом единстве с остальными областями культуры, и в ее специфическом содержании обязательно проявляются черты и особенности, свойственные данной культуре в целом. Взаимодействие правовой и других областей культуры происходит в результате взаимосвязи и взаимовлияния однотипных культурных комплексов, принадлежащих к разным культурным сферам (политической, экономической, нравственной, правовой и пр.).

Элементы, образующие правовую культуру, одновременно включены и в другие структуры. Так, право входит в систему социальных норм; правоотношения — в систему общественных отношений; правовые учреждения - в систему социальных институтов; правосознание - в систему общественного сознания; правовое поведение - в систему всей социальной деятельности людей (см. табл. 1).

Структурные связи правовой культуры

Таблийа 1

\begin{tabular}{|c|c|c|c|c|}
\hline \multirow{2}{*}{$\begin{array}{l}\text { Культурные } \\
\text { комплексы }\end{array}$} & \multicolumn{4}{|c|}{ Культурные области } \\
\hline & $\begin{array}{c}\text { Политика как область } \\
\text { культуры }\end{array}$ & Правовая культура & Этическая культура & $\begin{array}{c}\text { Эстетическая } \\
\text { культура }\end{array}$ \\
\hline $\begin{array}{c}\text { Общественные } \\
\text { отношения }\end{array}$ & $\begin{array}{c}\text { Политические отно- } \\
\text { шения }\end{array}$ & Правоотношения & $\begin{array}{c}\text { Нравственные от- } \\
\text { ношения }\end{array}$ & $\begin{array}{l}\text { Эстетические } \\
\text { отношения }\end{array}$ \\
\hline $\begin{array}{c}\text { Общественное } \\
\text { сознание }\end{array}$ & $\begin{array}{l}\text { Политическое } \\
\text { сознание }\end{array}$ & Правосознание & $\begin{array}{l}\text { Нравственное } \\
\text { сознание }\end{array}$ & $\begin{array}{l}\text { Эстетическое } \\
\text { сознание }\end{array}$ \\
\hline $\begin{array}{c}\text { Социальные } \\
\text { нормы }\end{array}$ & Политические нормы & Право & $\begin{array}{c}\text { Мораль как система } \\
\text { норм }\end{array}$ & $\begin{array}{c}\text { Эстетические } \\
\text { нормы }\end{array}$ \\
\hline $\begin{array}{l}\text { Социальные } \\
\text { учреждения } \\
\text { (институты) } \\
\end{array}$ & $\begin{array}{c}\text { Политические } \\
\text { органы и учреждения }\end{array}$ & $\begin{array}{c}\text { Правовые } \\
\text { учреждения } \\
\text { (институты) } \\
\end{array}$ & $\begin{array}{c}\text { Общественные } \\
\text { организации } \\
\text { и институты } \\
\end{array}$ & $\begin{array}{c}\text { Художественно- } \\
\text { просветительские } \\
\text { учреждения } \\
\end{array}$ \\
\hline $\begin{array}{c}\text { Социальное } \\
\text { поведение } \\
\text { (деятельность) }\end{array}$ & $\begin{array}{l}\text { Политическая } \\
\text { деятельность }\end{array}$ & $\begin{array}{l}\text { Правовое } \\
\text { поведение }\end{array}$ & $\begin{array}{c}\text { Нравственное } \\
\text { поведение } \\
\text { (деятельность) }\end{array}$ & $\begin{array}{c}\text { Художественно- } \\
\text { эстетическая } \\
\text { деятельность }\end{array}$ \\
\hline
\end{tabular}

Функциональные связи, взаимодополнение и взаимоподкрепление родственных элементов в этих системах обеспечивают соответствие друг другу тех областей культуры, в системы которых они одновременно входят.

В случаях же несоответствия мы имеем дело с дезорганизацией нормальной деятельности систем (например, преступ- ность и иные виды социальной патологии и отклоняющегося поведения).

Факторы, порождающие культурную общность и культурные различия, распространяют свое влияние на все сферы общественной жизни. Поэтому в составе правовой культуры функционируют и определенным образом взаимодействуют правовые субкультуры. Правовая субкультура 
складывается из элементов, которые являются аналогами названных выше культурно-правовых комплексов, с тою лишь разницей, что праву как совокупности государственных нормативных актов в субкультуре эквивалентны неписаные кодексы, правовым учреждениям - неформальные институты, а правовое поведение характеризуется специфическими для данной среды проявлениями, типичными способами исполнения (а в некоторых случаях и нарушения) отдельных правовых предписаний.

Исследования показывают, что определенным своеобразием отличается и правосознание различных подкультурных групп. С учетом особой роли правового фактора для жизнедеятельности некоторых групп выделяются специализированные правовые культурные образования, к числу которых относится, например, криминальная субкультура. Здесь усматривается своя шкала предпочтений и система норм, четко очерченные роли, идеалы, традиции, символы. Таким образом, правосознание входит в состав правовой культуры разных общностей и подобществ, где оно только и может быть познано. Это положение важно для практической организации исследований, методов изучения, анализа и прогноза.

Являясь одним из компонентов правовой культуры, правосознание выполняет функции оценки всех ее остальных компонентов: права как совокупности норм, правовых институтов, правового поведения (собственного и других людей), а также порождаемых правовыми нормами правоотношений, которые, как об этом свидетельствует общественная практика, реализуется в жизни не изолированно, а в системе остальных общественных отношений и в тесной связи с ними.

Современный строй общественных отношений (политических, экономических, моральных и т. д.) составляет в своей совокупности систему социальных ценностей, охраняемых различными формами социального контроля, в том числе и правом, которое реализует свои охранительные функции с помощью фиксируемых им прав и обязанностей по отношению к охраняемым ценностям, т. е. через правоотношения. Так, уголовное право охраняет социальные ценности общества путем системы запретов и угрозы наказанием за их нарушение. Личность, ее честь и достоинство, ее физическая неприкосновенность и имущество охраняются уголовным правом, и посягательство на эти ценности - coвершение преступления - влечет возникновение уголовно-правового отношения: право государства подвергнуть виновного наказанию и его обязанность это наказание понести.

Тот же механизм действует в отношении остальных социальных ценностей, охраняемых уголовным правом. Вся система предусмотренных уголовным правом мер охраны социальных ценностей нашего общества и их реализация в уголовных правоотношениях складывается в специфическую область государственной деятельности — в уголовную политику. Ее направления и эффективность оцениваются правосознанием граждан, их различных социальных образований (групп, категорий и т.д.).

Система норм уголовнопроцессуального права обеспечивает необходимые средства изобличения лиц, виновных в совершении преступлений, и охраны невиновных от необоснованного привлечения к уголовной ответственности и осуждения. Каждый гражданин участник уголовного процесса является субъектом процессуальных отношений и носителем предусмотренных процессуальными нормами прав и обязанностей. Процессуальные средства обеспечения достижения целей уголовного процесса, в особенности степени охраны личности от необоснованного вторжения правоохранительных органов в область их законных интересов, и характер реализации этих средств при осуществлении властных полномочий компетентными должностными лицами можно условно назвать уголовнопроцессуальной политикой, которая тоже оценивается правосознанием граждан.

Если правосознание отражает правовую культуру и проявляется в ней, то его исследование возможно путем анализа тех культурных элементов, в которых оно объ- 
ективируется, получает осязаемый выход. Различая в правовой культуре определенную духовную деятельность и ее продукты, можно выделить два типа проявлений правосознания.

Во-первых, в поведении, включающем правотворчество, правоприменительную и правоохранительную деятельность, законопослушное или противоправное поведение, правовое просвещение и воспитание, научно-правовую деятельность и иные виды духовного производства.

Во-вторых, в состоянии и результатах этой деятельности, включающих само право и его институты; директивные акты и научные труды; правовую документацию (например, уголовные дела); произведения искусства и публицистики; вербальные проявления сознания как в интимном, так и в официальном общении (письма, дневники и пр.).

Многие из перечисленных форм традиционно изучались юриспруденцией, но не с точки зрения функционирования и отражения правового сознания и не теми методами, которые пригодны для прочтения информации о правосознании, закодированной в этих источниках.

Исследование не может проходить иначе, чем через реконструкцию идеального по реальным действиям и их результатам. По принципу обратной связи культурные формы проявления правосознания одновременно служат и средствами его формирования или деформации, источниками правового опыта, каналами распространения правовой культуры. Отражаясь в сознании, они отчасти целенаправленно, a большей частью стихийно формируют должные или искаженные взгляды, оценки, установки и т. П.

В отличие от иных сфер сознания специфику правосознания составляет осознание и переживание связанности явлений с юридическими последствиями (действительными, мнимыми или желательными), соотношение их с государственноправовым регулированием, с юридическими правами, обязанностями и санкциями. У правосознания свой угол зрения на действительность, особый язык, соответствующая система понятий и категорий, особые критерии и способы оценок, особые цели и средства их осуществления. Поэтому, правовое сознание отличается от иных сфер гносеологией (познавательный аппарат), аксиологией (система ценностей и способов оценки), праксиологией (методы управления практической деятельностью). Соответственно этому мы можем в дальнейшем говорить о трех функциях правосознания: познавательной, оценочной и регулятивной.

Соответственно этим трем функциям (познавательной, оценочной и регулятивной) определяются основные функциональные компоненты правосознания. Познавательной деятельности соответствует определенная сумма юридических знаний и умений ими пользоваться или правовая подготовка. Оценочной функции отвечает система оценок н мнений по юридическим вопросам или оценочные отношения к праву и практике его исполнения и применения. Действие регулятивной функции осуществляется за счет правовых установок, организуемых в систему ценностных ориентации (см. табл. 2).

Таблица 2

Функциональная структура правосознания

\begin{tabular}{|c|c|c|c|}
\hline $\begin{array}{c}\text { Основные функции } \\
\text { правосознания }\end{array}$ & $\begin{array}{c}\text { Психические компоненты } \\
\text { (сферы) }\end{array}$ & $\begin{array}{c}\text { Результаты функциониро- } \\
\text { вания }\end{array}$ & Эмпирические показатели \\
\hline Познавательная & Интеллектуальные & Правовая подготовка & $\begin{array}{c}\text { Юридические знания и } \\
\text { умения }\end{array}$ \\
\hline Оценочная & $\begin{array}{c}\text { Интеллектуально- } \\
\text { эмоциональные }\end{array}$ & $\begin{array}{c}\text { Ценностные отношения к } \\
\text { праву и практике его при- } \\
\text { менения }\end{array}$ & $\begin{array}{c}\text { Оценочные суждения } \\
\text { (мнения) }\end{array}$ \\
\hline Регулятивная & Интеллектуально- \\
эмоционально-волевые & $\begin{array}{c}\text { Правовые установки и } \\
\text { ориентации }\end{array}$ & $\begin{array}{c}\text { Поведенческие позиции } \\
\text { (решения) }\end{array}$ \\
\hline
\end{tabular}

Таким образом, в операциональных 
сферу общественного, группового и индивидуального сознания, отражающую правовую действительность в форме юридических знаний и умений ими пользоваться, оценочных отношений к праву и практике его применения, правовых установок и ценностных ориентаций, регулирующих человеческое поведение в юридически значимых ситуациях.

В основе приспособительной деятельности человека лежит минимальная сумма знаний об объективных условиях этой деятельности.

Правовая подготовка людей не исчерпывается их формальными юридическими знаниями. Можно обладать знаниями, но не уметь ими пользоваться. Необходимо учитывать степень практического владения этими знаниями. Уровень правовых знаний и умение применить их на практике поддаются эмпирической проверке с достаточной степенью точности.

Познавая действительность, люди не остаются равнодушными к результатам познания, которые соотносятся с прошлым опытом, потребностями, интересами, целями их деятельности. Познанные свойства объектов определенным образом переживаются. Возникает новое, на этот раз уже интеллектуально-эмоциональное образование - психическое отношение к объектам познания и практической деятельности (полезно или вредно, приемлемо или неприемлемо и т. п.). Таким образом, отношение выражается в оценке, т. е. в признании ценности чего-либо с точки зрения индивида, группы, общества. Профильтрованные через личный опыт и правовую практику субъекта, познаваемые им разные стороны и явления правовой жизни точно так же вызывают к себе определенные отношения и, будучи значимы для личности, приобретают известный смысл, подвергаются оценке, квалифицируются как ценности (позитивные или негативные).

В структуре правосознания выделяется несколько доминирующих групп оценочных отношений: во-первых, отношения к праву, его принципам, институтам и нормам, во-вторых, отношения к правомерному и противоправному поведению окру- жающих, в-третьих, отношения к правоохранительным органам и их деятельности, в-четвертых, отношения к собственному правовому поведению (правовая самооценка). Отношения к правовым ценностям выражаются в оценочных суждениях, которые могут быть выявлены в эмпирическом исследовании с большей или меньшей степенью соответствия подлинным оценкам обследуемых лиц.

Сами по себе оценочные отношения, как интеллектуально-эмоциональные образования, еще не обладают способностью практической реализации без психических сил, играющих роль пусковых и движущих механизмов деятельности. Такую энергетическую роль выполняет волевой компонент, формирующий готовность действовать в определенном направлении. Включение этого компонента приводит к новым, теперь уже интеллектуальноэмоционально-волевым образованиям, социальным установкам.

Под установкой обычно понимают тенденцию или предрасположенность личности воспринимать и оценивать какойлибо объект определенным образом и готовность действовать в отношении данного объекта в соответствии с этой оценкой. Динамический, энергетический характер отличает, на наш взгляд, установку от оценочного отношения, которое само по себе остается созерцательно-эмоциональным. Когда объектом установки служат различные правовые ценности, мы говорим о правовых установках.

В своей совокупности установки организуются в систему ценностных ориентации. Ценностные ориентации - это относительно устойчивая система установок, определенным образом ориентированная на социальные ценности и направляющая поведение людей по отношению к этим ценностям в условиях их сложного взаимодействия. Доминирующие установки образуют направленность личности, определяют ее позицию и характеризуют содержательную сторону ценностных ориентации.

Правовая ориентация есть совокупность правовых установок индивида или общности, непосредственно формирующая 
внутренний план, программу деятельности в юридически значимых ситуациях.

Таким образом, регулятивная функция правосознания осуществляется посредством правовых установок и ориентаций, синтезирующих в себе все иные источники правовой активности. Если оценочные отношения более или менее успешно могут быть выявлены на основе оценочных суждений «в статике», то степень их действенности, включенности в непосредственные стимулы волевого поведения таким путем усмотреть невозможно.

Эмпирическое исследование правовых установок и ориентаций требует изучения самого поведения в реальной или экспериментальной ситуации. При этом эксперимент должен с достаточным приближением воспроизводить объективные и субъективные факторы, имеющие место в реальной жизни.

Исследование правового сознания отдельных групп населения и различных категорий преступников показало, что общий объем осведомленности в рамках требований, которые определены в качестве минимально необходимых для правомерного поведения, достаточно высок у всех испытуемых. Получены результаты, указывающие на то, что правовая осведомленность хотя и является существенной предпосылкой нормативного поведения, но сама по себе недостаточна для того, чтобы поведение было правомерным. Как оказалось, основные деформации правосознания, которые служат источником отклоняющегося поведения, лежат не в когнитивно-познавательной сфере, а на уровне оценочных отношений к праву и практике его применения, и в области правовых установок и ценностных ориентации.

В связи с этим исследование правосознания целесообразно сосредоточить на этих сферах. Причем при проведении массового исследования основное внимание предполагается уделить одному из функциональных компонентов правосознания - оценочным отношениям населения к проблемам преступности, коррупции и мерам борьбы с ней, которые и составляют основное содержание общественного мне- ния в интересующей нас сфере.

В операциональных целях общественное мнение в правовой сфере определяется нами в качестве одного из компонентов правосознания как свойственная различным группам и общностям система оценочных суждений о праве и практике применения.

Необходимой предпосылкой общественного мнения является наличие общественного интереса к явлению, отношение к которому является предметом изучения в общественном, групповом и индивидуальном правосознании. Отношение и мнение взаимосвязаны оценкой предмета (явления). Они не могут сформироваться вне его оценки (положительной или отрицательной), а оценка явления возможна лишь при наличии внимания, интереса к нему. Поэтому изучение общественного мнения о преступности и мерах борьбы с ней это в значительной мере исследование уровня общественного интереса к данным проблемам, т. е. осознания актуальности.

Общественное мнение о преступности и мерах борьбы с нею, рассматриваемое как совокупность оценочных суждений об указанных явлениях, составная часть правосознания, не может изучаться изолированно, вне его связи с общими социальными ориентациями субъекта, а, следовательно, с его политическим и нравственным сознанием.

Правосознание занимает определенное место в общей системе оценок, суждений, мнений, всего мировоззрения субъекта. Специфические черты этой системы, порождаемые объективными условиями современного строя общественных отношений, а также групповыми и субкультурными особенностями сосуществования людей, ведут к образованию в большей или меньшей степени соответствующих друг другу типических видов связи между общими социальными ориентациями, политическими, нравственными и правовыми взглядами людей. Поэтому и предмет исследования, его проблемы и гипотезы формулируются, как общее правило, исходя из того, что правосознание составляет часть общей системы ориентации, взглядов, убеждений отдельных лиц, групп и 


\section{общества.}

\section{2. Характеристика ранее проведен- ных исследований.}

В разное время в нашей стране был проведен ряд эмпирических исследований правосознания применительно к сфере борьбы с преступностью, которыми, с различной степенью достоверности были установлены некоторые закономерности, характеризующие состояние правосознания граждан, а также отличия в правосознании лиц законопослушных, правонарушителей и преступников ${ }^{1}$. Отдел боль-

1 Ратинов А. Р. Психологические основы расследования преступлений : дис. ... д-ра юрид. наук. 1967; Ратинов А. Р. Структура и функции правосознания // Социология права. Вильнюс. 1970; Структура правосознания и некоторые методы его исследования // Методология и методы социальной психологии. М., 1977; Ефремова Г. Х., Ратинов А. Р. Правовая психология и преступность молодежи. М., 1976; Ефремова Г. Х. Криминологическая характеристика правосознания молодых правонарушителей : дис. ... канд. юрид. наук. М., 1973; Ефремова Г. Х. Криминологические проблемы общественного мнения : Дис. ... д-ра юрид. наук. М. 1991; Долгова А. И. Криминологические проблемы взаимодействия социальной среды и личности : дис. ... д-ра юрид. наук. М., 1980; Дамаскин О. В. Криминологическая характеристика правосознания армейской молодежи : дис. ... канд юрид. наук. М., 1980; Дамаскин О. В. Криминологические проблемы правовой работы в Вооруженных Силах Российской Федерации : дис. ... д-ра юрид. наук. М., 2004; Пристанская О. В. Криминологическая характеристика правосознания и его особенностей у преступников молодого возраста : дис. ... канд. юрид. наук. М. 1985; Пристанская О. В., Юцкова Е. М. Методика криминологического изучения правосознания и общественного мнения о преступности. М., 1989; Ситковская О. Д. Психология уголовной ответственности. М., 1998; Ситковская О. Д. Новые направления судебнопсихологической экспертизы. М., 2000; Ситковская О. Д. Аффект. Криминально-психологическое исследование. М., 2001; Овчинский В. С. Криминологические, уголовно-правовые и организационные основы борьбы с организованной преступностью в Российской Федерации : дис. ... дра юрид наук. М., 2004; Общественное мнение о преступности и мерах борьбы с ней. М., 1977; Личность преступника как объект психологического исследования. М., 1979; Актуальные проблемы правосознания в современной России. М., 2005; Алексеев А. И., Овчинский В. С., Побегайло Э. Ф. Российская уголовная политика: преодоление кризиса. М., шее количество вариантов поведения считают допустимыми с правовой точки зрения, оставляя для себя гораздо больше возможностей для нарушения установленных правил и норм. Это объясняется не отсутствием соответствующей правовой информации и не слабым владением имеющимися знаниями, а несогласием с законом. Преступники имеют наиболее точные представления о тех видах запретного поведения, за которые они сами привлекались к уголовной ответственности. Превосходство конкретных юридических знаний у лиц с отклоняющимся поведением связано, чаще, с их собственным негативным опытом.

Значительная часть молодежи характеризуется не сложившимися ценностными ориентациями в правовой сфере. Из наиболее важных по содержанию и удельному весу дефектов правосознания, установленных предшествующими исследованиями, необходимо выделить следующие.

Наличие значимых расхождений с законодателем в оценке некоторых охраняемых законом благ. Такие расхождения выражаются, в частности, в более снисходительном по сравнению с законом и установившейся карательной практикой отношении к некоторым тяжким преступлениям (вымогательство взятки, дача взятки, спекуляция) и, кроме того, к лжесвидетельству, а также нигилистическом отношении к процессуальным гарантиям, обеспечивающим от необоснованного привлечения граждан к уголовной ответственности, осуждения и ограничения их личных прав.

Непризнание значительной частью опрошенных совершения преступления в состоянии опьянения обстоятельством, отягчающим ответственность. Недостаточно высокий уровень оценки эффективности органов правоохраны, особенно в части раскрываемости преступлений следственными органами. Недооценка значимости социальной роли, выполняемой судьями, что находит свое проявление в от-

2006; Дамаскин О. В. Коррупция: состояние, причины, противодействие. М., 2009; Корякин В. М. Коррупция в Вооруженных Силах: теория и практика противодействия. М., 2009. 
носительно невысоком ранге, отводимом гражданами профессии судьи в ряду других юридических профессии.

Широкое распространение замены правовых оценок и убеждений (т. е. правосознания) нравственными оценками. Этот дефект оказывает весьма отрицательное влияние на поведение при наличии существенных деформаций, а особенно незавершенности процесса формирования нравственного сознания, что весьма характерно для подростков и молодежи (искажения представления о товарищеском долге и пр.). Этот же дефект очень явно обнаруживается у различных категорий взрослых преступников, которые «облагораживают» побудительные причины совершенных ими преступлений. Среди преступников отмечается низкий уровень солидарности с уголовным законом. Степень усвоения правовых норм в качестве признаваемых у лиц с отклоняющимся поведением гораздо ниже, чем у законопослушных. Преступники зачастую воспринимают правовые нормы как навязанные извне принудительные правила, исполняемые под страхом наказания. Преступники характеризуются настороженным, недоверчивым, отчужденным, а подчас и враждебным отношением к органам правопорядка и правосудия. Работа органов дознания и следствия представляется им малоэффективной, а карательная практика чрезмерно суровой. Преступники отличаются примирительно-одобрительным отношением к фактам преступной деятельности, что связано с позицией социальной пассивности и невмешательства в противоправное поведение других лиц в расчете на взаимность. Характерное для значительного числа подростков, достигших возраста уголовного совершеннолетия, неумение провести в своем поведении грань между свойственным их возрасту озорством и преступлением.

Указанные выше особенности правосознания, установленные предыдущими исследованиями, подлежат проверке с целью выявления возможных изменений, происшедших в общественном сознании за последние годы в связи с новыми социально-экономическими, общественно- политическими, криминальными и коррупционными факторами.

Достоверность полученных ранее данных, их теоретическая и практическая значимость, требует в современных условиях дальнейшей проверки, учитывая тенденцию сокращения количества и качества достоверных научных исследований, их подмену конъюнктурными политизированными опросами, проводимыми отдельными информационными центрами. В настоящее время актуализируется потребность систематического мониторинга правосознания граждан, более широкого социологического обеспечения криминолого-правовых исследований, в интересах их доказательности, достоверности, теоретической и практической значимости, создания реальной комплексной системы правового обучения и воспитания молодежи, с учетом актуализации проблемы противодействия криминальной субкультуре и экстремистским проявлениям в современном обществе.

\section{3. Задачи планируемых исследова- ний.}

Общими задачами планируемых исследований являются: выяснение реального состояния и содержания общественного мнения о преступности и мерах борьбы с ней; выяснение характера влияния положительных и отрицательных особенностей общественного мнения на правомерное и противоправное поведение; выяснение роли общественного мнения в формировании активно положительной, нейтральной или негативной позиции в отношении сотрудничества с правоохранительными органами и непосредственного участия в борьбе с преступностью. Конкретизация этих основных задач позволяет выделить некоторые проблемы, решение которых желательно осуществить в исследовательской работе.

1) Наличие связи между общиими социальными ориентациями субъекта и характером его правовых убеждений, а, следовательно, и его правового поведения. Существование такой связи удалось проследить, например, в ходе исследования нравственного и правового сознания, когда данные по индикаторам общих социаль- 
ных ориентаций субъекта (главным образом «включенности» или «отчужденности»), его нравственного и правового сознания сопоставлялись с данными об оценке опрашиваемыми детерминант законопослушного поведения. У лиц, указавших, что люди действуют правомерно в силу солидарности с законом или потому, что боятся потерять уважение окружающих (стремление идентифицировать себя с законопослушной средой как своей референтной группой), оказался значительно более высокий уровень социально позитивных общих ориентации, нравственных и правовых оценок по сравнению с теми, кто считал, что от противоправного поведения удерживает в первую очередь страх наказания.

2) Распространенность уголовноправового ригоризма, выражающегося в неумеренных карательных притязаниях, основанных на ложном убеждении, что суровая репрессия и ее постоянное ожесточение являются наиболее надежным средством борьбы с преступностью. Подобное же явление, но в более широких размерах зафиксировано известными нам зарубежными исследованиями правосознания. Имеющиеся данные не дают, однако, ответа на вопрос о психологических источниках столь широкого распространения указанного явления. Кроме того, сопоставление данных разных исследований дает основание для сомнений в устойчивости зафиксированной исследованиями установки на ригоризм.

3) Оценка общественной опасности неосторожных преступлений. Отношение к неосторожным преступлениям выяснялось путем решения опрашиваемыми одного конкретного задания, в котором давалось описание неосторожного уничтожения чужого имущества, т. е. сравнительно не очень широко распространенного преступления. Представляется, что воспитание в гражданах должной предусмотрительности и чувства ответственности за безопасность себя и окружающих относится к числу наиболее актуальных задач правового воспитания.

4) Детерминанть законопослушного поведения. По данным прошлых исследований, среди субъективных факторов, де- терминирующих законопослушное поведение, наиболее распространенным является солидарность с конкретными принципами и нормами уголовного права, а страх наказания среди этих факторов занимает последнее ранговое место. Высокий уровень ссылок на солидарность с законом требует дополнительной проверки по конкретным индикаторам, поскольку нельзя исключить возможность известной доли декларативных ответов.

5) Иерархия правоохраняемых иенностей. По имеющимся данным, среди социальных благ, охраняемых уголовным законом, первое ранговое место принадлежит личности, а последнее - общественному порядку. Требуется проверка этого положения по дополнительным вариантам «наборов» преступлений для ранжировки и введение контрольных индикаторов уровня карательных притязаний за деяния, различающиеся по объекту посягательства.

6) Уровень общественного интереса $\kappa$ правовым явлениям. Вывод о недостаточно высоком уровне общественного интереса к правовым явлениям и проблеме борьбы с преступностью можно было сделать, судя по значительному числу уклонений от ответов на заданные вопросы. Поэтому уровень общественного интереса к этой проблеме (осознания ее актуальности) необходимо уточнить с помощью дополнительных индикаторов. Вся эта проблема тесно связана с проблемой «включенности» общественности в борьбу с преступностью.

7) Уровень понимания основ уголовного законодательства и уголовного судопроизводства. Недостаточный в ряде случаев уровень понимания основных, принципиальных положений, политических, нравственных основ уголовного законодательства и уголовного судопроизводства. Некоторые существенные положения подвергались уже исследованию, но круг охваченных вопросов, особенно в области уголовного права, далеко не полон и не отражает в достаточной мере уровня правовой культуры населения.

8) Отношение преступников к праву $и$ практике его применения, т. е. изучение содержания и особенностей правосознания 
различных категорий преступников. Согласно общей концепции о регулирующей роли правосознания в юридически значимом поведении, выдвинуто предположение о криминогенной роли деформаций правосознания. В генезисе различных видов правонарушений эти деформации имеют различные качественные и количественные характеристики, определяющие своеобразие основных типов преступного поведения. Проведенные исследования еще не дают полного и достоверного ответа на поставленные вопросы ввиду фрагментарности полученных данных. Существенно возрастает влияние телевидения и цифровых технологий на психологию межличностных отношений молодёжи ${ }^{1}$.

Суммируя рассмотренные выше задачи и вопросы, подлежащие разрешению, целесообразно исследование правосознания граждан по следующим основным направлениям:

- изучение связи общесоциальных ориентации и правосознания;

- изучение ценностных ориентации в правовой сфере;

- актуальность проблемы преступности и мер борьбы с ней;

- изучение мнений о детерминации законопослушного поведения;

- изучение мнений о причинах преступного поведения и мерах борьбы с преступностью;

- изучение отношений к принципам уголовного права и уголовного судоустройства;

- изучение реакций на преступное поведение;

- изучение уровня карательных притязаний;

- изучение отношений к неосторожным преступлениям;

- изучение соотношений массового, группового и индивидуального правосознания;

— престиж права, правопорядка и за-

\footnotetext{
1 Противодействие современной преступности. Криминологические, уголовно-правовые и уголовно-процессуальные аспекты : монография / под общ. ред. чл.-корр. РАН А. Н. Савенкова. М.: ЮНИТИ-ДАНА: Закон и право, 2019.
}

конности. Оценка эффективности правовой системы;

- престиж правоохранительных органов и оценка эффективности их деятельности;

- оценка эффективности деятельности органов дознания и следствия;

- оценка престижа и эффективности деятельности органов правосудия;

- проблема престижа и эффективности деятельности органов исполнения наказаний;

- престиж юридических профессий;

— общественное мнение о латентной преступности;

- общественное мнение о функционировании общественных институтов и включенности граждан в борьбу с преступностью;

- изучение отношения правонарушителей к проблеме преступности и мерам борьбы с ней;

- изучение профессионально-юридического общественного мнения о преступности и мерах борьбы с ней;

- влияние цифровых технологий на психологию межличностного общения и деформацию личности.

Общая гипотеза исследования строится на основании эмпирически доказанного положения о том, что состояние правового сознания в условиях нашего общества не является однородным, а предопределяется социально-экономическими и иными факторами и характеризуется статистически значимыми различиями. Отсюда вытекает, что общественное мнение о преступности и мерах борьбы с ней, при доминировании совпадающих позиций по основным стержневым вопросам проблемы, одновременно характеризуется многообразием суждений и оценок по поводу отдельных явлений правовой жизни общества, часть из которых представляет собой нежелательные деформации, а другая часть прогрессивные и опережающие средний уровень элементы общественного сознания.

Эта информация и предлагаемый подход позволяют определить доминирующие ориентации и тенденции поведения, повысить целенаправленность и результатив- 
ность профилактики и противодействия противоправным проявлениям, что подтверждается апробацией и практикой применения ${ }^{1}$.

\section{4. Перспективы.}

Происходящее осмысление проблем преступности в XXI в. - противодействие криминальной субкультуре и проявлениям экстремизма - в современных условиях продолжающейся коронавирусной пандемии, нарастания экономических, социальных и военных проблем национальной и международной безопасности позволяет сделать ряд выводов и конструктивных предложений.

Современная преступность, как наиболее острая форма посягательства на правопорядок, общественную безопасность в нашей стране, становится составной частью гибридной борьбы, ведущейся против России агрессивными силами США, их союзниками и зависимыми сателлитами, наряду с экономическими санкциями, используемыми как средство экономического давления и средствами информационной идеологической борьбы. Поэтому комплекс мер противодействия выходит за рамки традиционных уголовноправовых мер, включая меры экономического, социального, организационного противодействия.

Актуализируются вопросы интеллектуального, психологического, идеологического влияния на умы людей в процессе формирования ценностных ориентаций, поведенческих позиций людей, осмысления жизненно важных приоритетов и цен-

\footnotetext{
1 Противодействие современному экстремизму и терроризму : науч.- практ. пособие / О. В. Дамаскин, В. В. Красинский, А. В. Козлов; под общ. ред. чл.-корр. РАН А. Н. Савенкова. М.: ЮНИТИ-ДАНА: Закон и право, 2019; Дамаскин O. В. Преступность в XXI веке: проблемы и перспективы: монография. М.: Юрлитинформ, 2020; Дамаскин О. В., Красинский В. В. Криминологическая характеристика механизма вовлечения несовершеннолетних в противоправную деятельность // Государство и право. 2020. № 8. С. 41-54; Ясницкая М. И. Криминологические аспекты противодействия современному молодежному экстремизму // Военное право. 2020. — № 4. - C. 193-205.
}

ностей в сфере общественных отношений, законности и правопорядка.

Приоритетными

нравственноправовыми ценностями становятся патриотизм, воля, творчество и работоспособность, преодоление корыстноэгоистических, либерально-индивидуалистических воззрений, укрепление коллективистских отношений в интересах сплочения общества, повышения организованности и результативности усилий по преодолению трудностей.

Актуализируется потребность правового обучения и воспитания граждан, как комплексной системы формирования их правового сознания и поведения. При этом в приоритетном внимании нуждается молодежь.

Коронавирусная пандемия стала катализатором процесса переосмысления приоритетов и ценностей в интересах национальной и международной безопасности. При этом, не повторяя ошибок прошлого, при решении старых и новых проблем главной ценностью остаются жизнь и безопасность людей, обращение к традиционным нравственным ценностям.

Актуализируются экологические проблемы сбережения земли, воздуха, воды, как жизненно важных основ жизни человечества. Сохраняется потребность международного сотрудничества под эгидой Совета Безопасности ООН, в интересах повышения эффективности использования ресурсов, укрепления мер доверия в международном сотрудничестве, в интересах мира и безопасности человечества.

Приоритеты и ценности капитализма, как системы организации общества, представляются исчерпанными, что предполагает потребность ускоренного перехода к обновленной форме общественных отношений, основной сущностью которой станет принцип социальной справедливости, как объединяющей идеи общественного сотрудничества.

Значительно возрастает организующая роль государства, как выразителя жизненно важных интересов большинства трудящихся граждан нашего общества, преодоление доминирования идеологии либерализма и капитализма, его негативных по- 
следствий в жизненно важных сферах жизни.

Ключевой проблемой мирного кадрового обеспечения замены либерально ориентированного слоя в системе государственной власти и управления в интересах суверенитета и национальной безопасности в условиях нарастания угрозы военной агрессии, в интересах большинства народа, становится использование общественно, национально и патриотично ориентированных организованных сил обороны и безопасности.

Состоявшееся 22 октября 2020 г. яркое программное мировоззренческое выступление Президента Российской Федерации В. В. Путина на форуме Международного дискуссионного клуба «Валдай» по своему содержанию и направленности, созвучное жизненно важным интересам и позиции большинства трудящихся граждан нашей страны, научному осмыслению современного состояния и перспектив развития, открывает путь реализации и защиты национальных интересов, дальнейшему укреплению суверенитета и национальной безопасности Российской Федерации в трансформирующемся мире.

\section{Библиография}

1. Актуальные проблемы правосознания в современной России. - М., 2005.

2. Алексеев, А. И. Российская уголовная политика: преодоление кризиса / А. И. Алексеев, В. С. Овчинский, Э. Ф. Побегайло. - М., 2006.

3. Дамаскин, О. В. Коррупция: состояние, причины, противодействие / О. В. Дамаскин. - М., 2009.

4. Дамаскин, О. В. Криминологическая характеристика механизма вовлечения несовершеннолетних в противоправную деятельность / О. В. Дамаскин, В. В. Красинский // Государство и право. - 2020. - № 8. - С. 41-54.

5. Дамаскин, О. В. Криминологическая характеристика правосознания армейской молодежи : дис. ... канд. юрид. наук / О. В. Дамаскин. - М., 1980.

6. Дамаскин, О. В. Криминологические аспекты детерминации современного экстремизма и терроризма : монография / О. В. Дамаскин. - М.: Юрлитинформ, 2018. - 264 с.

7. Дамаскин, О. В. Криминологические аспекты изучения правосознания и общественного мнения военнослужащих: методология и методика : научно-практическое пособие / О. В. Дамаскин. M., 2017.
8. Дамаскин, О. В. Криминологические проблемы правовой работы в Вооруженных Силах Российской Федерации : дис. ... д-ра юрид. наук / О. В. Дамаскин. - М., 2004.

9. Дамаскин, О. В. Преступность в XXI веке: проблемы и перспективы : монография / О. В. Дамаскин. - М.: Юрлитинформ, 2020. $264 \mathrm{c}$.

10. Дамаскин, О. В. Транснациональная организованная преступность: проблемы международной и национальной безопасности : монография / О. В. Дамаскин. - М.: Юрлитинформ, 2019. - 344 с.

11. Долгова, А. И. Криминологические проблемы взаимодействия социальной среды и личности : дис. д-ра юрид. наук / А. И. Долгова. M., 1980.

12. Ефремова, Г. Х. Криминологическая характеристика правосознания молодых правонарушителей : дис. ... канд. юрид. наук / Г. Х. Ефремова. - М., 1973.

13. Ефремова, Г.Х. Криминологические проблемы общественного мнения : дис. ... д-ра юрид. наук / Г. Х. Ефремова. - М., 1991.

14.Ефремова Г. Х. Правовая психология и преступность молодежи / Г. Х. Ефремова, А. Р. Ратинов. - М., 1976.

15. Корякин, В. М. Коррупция в Вооруженных Силах: теория и практика противодействия : монография / В. М. Корякин. - М., 2009.

16. Личность преступника как объект психологического исследования. М. 1979.,

17. Лунеев, В. В. Эпоха глобализации и преступность : монография / В. В. Лунеев - М.: Норма: ИНФРА-М, 2015. — 272 с.

18. Овчинский, В. С. Криминологические, уголовно-правовые и организационные основы борьбы с организованной преступностью в Российской Федерации : дис. ... д-ра юрид наук / В. С. Овчинский. - М., 2004.

19. Общественное мнение о преступности и мерах борьбы с ней. - М., 1977.

20. Преступность XXI века. Транснациональный характер. Теневая экономика. Противодействие современной преступности. Криминологические, уголовно-правовые и уголовно-процессуальные аспекты : монография / под общ. ред. чл.-корр. РАН А. Н. Савенкова. М.: ЮНИТИ-ДАНА: Закон и право, 2019. — 567 с.

21. Пристанская, О. В. Криминологическая характеристика правосознания и его особенностей у преступников молодого возраста : дис. ... канд. юрид. наук / О. В, Пристанская. - М., 1985.

22. Пристанская, О. В. Методика криминологического изучения правосознания и общественного мнения о преступности / О. В. Пристанская, Е. М. Юцкова. - М., 1989.

23. Противодействие современной преступности. Криминологические, уголовно-правовые и уголовно-процессуальные аспекты : монография / под общ. ред. чл.-корр. РАН А. Н. Савенкова. М.: ЮНИТИ-ДАНА: Закон и право, 2019. — 567 с. 
24. Противодействие современному экстремизму и терроризму : науч.- практ. пособие / О. В. Дамаскин, В. В. Красинский, А. В. Козлов; под общ. ред. чл.-корр. РАН А. Н. Савенкова. М.: ЮНИТИ-ДАНА: Закон и право, 2019. - 143 с.,

25. Ратинов, А. Р. Психологические основы расследования преступлений : дис. ... д-ра юрид. наук / А. Р. Ратинов. - М., 1967.

26. Ратинов, А. Р. Структура и функции правосознания / А. Р. Ратинов // Социология права. - Вильнюс, -1970.

27. Савенков А. Н. Государство и право в период кризиса современной цивилизации : монография / А. Н. Савенков. - М.: Проспект, 2020. - $448 \mathrm{c}$.

28. Ситковская, О. Д. Аффект. Криминальнопсихологическое исследование / О. Д. Ситковская. - M. 2001.
29. Ситковская, О. Д. Новые направления судебно-психологической экспертизы

О. Д. Ситковская. - М. 2000.

30. Ситковская, О. Д. Психология уголовной ответственности / О. Д. Ситковская. - М. 1998.

31. Структура правосознания и некоторые методы его исследования // Методология и методы социальной психологии. - М., 1977.

32. Трансформация парадигмы права в цивилизационном развитии человечества : доклады членов РАН / под общ. ред. чл.-корр. РАН А. Н. Савенкова. - М.: ИГП РАН, 2019. — 408 с.

33. Ясницкая, М. И. Криминологические аспекты противодействия современному молодежному экстремизму // Военное право. 2020. — № 4. - C. 193-205. 